\title{
Building Geo-Database for Geotechnical Properties of Thi-Qar Governorate Area Using Modern Digital Techniques
}

\author{
Kasim A.Abed Al-Abas ${ }^{1}$, Sophia R. Al-timimy ${ }^{2}$, Kamil Y. Husain ${ }^{3}$, Saleem Ethaib ${ }^{4}$,Hasan \\ Swadi Njeban ${ }^{5}$, Falah H. Rahil ${ }^{6}$, Abdul-Razzak T. Ziboon ${ }^{7}$ \\ \{ksmabd@stu.edu.iq ${ }^{1}$, sophia.razaq@stu.edu.iq ${ }^{2}$,kamil.hussain@stu.edu.iq $\left.{ }^{3}\right\}$ \\ Al-Shatrah Technical Institute, Southern technical university ${ }^{1,2,3}$ \\ The University of Thi-Qar ${ }^{4,5}$ \\ The University of Technology 6,7
}

\begin{abstract}
The construction field is developed together with other economic activities around the world. But the construction still is an expensive field because of proper investigation under the surface laboratory test, as well as it is important but needs a lot of time and cost for the complex subsurface layer. So, this work aims to investigate soil properties using geotechnical techniques via remote sensing and GIS with multiprogram. to prepare the comprehension geodatabase including GPS, land cover, land use, to a large area. So, it will be a contribution by building a model too large area with a geotechnical model that will be reducing time, cost from a laboratory test, as well as a reference, can use instead of Certified laboratory investigate, as a first model for the governorate of ThiQar and can be used to other governorates.
\end{abstract}

Keywords: GIS-Rock work, Geotechnical map, Bearing capacity.

\section{Introduction}

A complex subsoil stratum below the ground surface, especially in Thi-Qar Governorate the case study of research. That led to, economical and safe design is important for construction projects. That makes Geotechnical investigation of geological materials most important. But facing geological surprises and adverse geological events leads to cost overruns and many times compromising the integrity of structures [1].In this sense, proper subsurface investigations play a crucial role in an economical and safe construction project. It is well known that the main objective of the sub-soil investigation of civil engineering is to determine the geotechnical properties of the soil underlying the site. Anyhow, identifying the subsoil stratum below the ground surface is a complicated process in large areas. For instance, the traditional methods of soil investigation include several processes including boring (or) drilling works, test pits, plate load tests, dynamic soil tests, and the laboratory chemical analysis of soil. By the same token, these processes are expensive and take a long time[2]. These reasons led to the aim of our research to use new approaches to overcome the defects of traditional soil investigations methods dependent on: Firstly, geographical information system (GIS) is one of the promising techniques that is widely applied for different purposes. GIS has the capability for acquiring, storing, manipulating, analysing, and displaying spatially referenced data. So GIS provides manage, analyse, effectively display and disseminate spatial information.[3] The spatially 
referenced data is defined according to its geographic location. Spatial or geographic data can be obtained from a variety of sources such as existing maps, satellite imagery, and the Global poisoning system (GPS). Secondly, GPS includes a network of satellites that continuously transmit coded information to precisely identify the location on earth by measuring the distance from the satellites [4]. The basic method for positioning with GPS can be done through the use of course acquisition C/A code on the carrier wave. By multiplying this travel time of the speed of transmission of the signal, the distance from the satellite to the receiver is obtained. In theory, it would be possible to determine the three-dimensional coordinates of the receiver from observations to three satellites [5]. Finally, the Rock Works Application as one of the important software programs utilized to produce maps sections, models, depended on soil properties such as (classification, borehole lithology, stratification, water level, concentrations of some of the soil materials). In that way, RockPlot3D can display three-dimensional surfaces that are based on grid models. These might result from drawdown surface (Hydrology/ Drawdown Surface) or from modelling stratigraphic surfaces in the Borehole Manager (Stratigraphy/ Structural Elevations) [6]. This technique can be applied to the investigation of soil and the geotechnical process by using GIS and rock work programs to protect geodatabase to land cover, land use, change detection over a large area. When cooperation with Previous studies as Al-Baghdadi research investigates the different soil contributions from (1.5 to $15 \mathrm{~m})$ to An-Najaf City by using contour map depend on the (SURFER 11)program. [7] But in al Basra city by investigation of the soil by 39 boreholes into a depth of $30 \mathrm{~m}$, the research tries to prove topographic of the case study are located within a flat plain called Mesopotamian Plain with a semi-arid climate. [8] In that case, we will use multi programs to protect the geotechnical model to the Thi-Qar governorate then do verification of it to build geodatabase use in projects with a new idea that can use to another governorate.

\section{Methodology}

In this research multi programs to produce a lithology model of soil to Thi-Qar governorate were used. Several applications were employed including Global Mapper v.12 and Surfer v. 9 to survey the elevation of the study area. Erdas v. 9.1 of Arc-map GIS 9.3 was used to build geodatabase and draw the 2D map of the study area. Rock Works v.15 was applied to make a longitude section with Integrate Arc-map GIS v. 9.3 and Rock Works v.15. Then the verification of research results was carried out to improve via civil works.

\subsection{Study Area}

Iraq is one of the most populous Arab countries with a population exceeding 40 million. Iraq is administratively divided into eighteen governorates as can be seen in Fig 1. The Thi-Qar governorate (alternatively spelled Dhi-Qar) is one of the 18th Iraqi governorates and is in the south. Al-Nassriya city is the capital of Thi-Qar governorate lies on the Euphrates River about $370 \mathrm{~km}$ southeast of Baghdad, near the ruins of the ancient Ur city [6]. This governorate lies to the north of Al-Basra with an area of about (13751.6) $\mathrm{km} 2$, between latitude $\left(30^{\circ} 40^{\prime}-32^{\circ} 00^{\prime}\right) \mathrm{N}$ and longitude $\left(45^{\circ} 40^{\prime}-47^{\circ} 10\right) \mathrm{E}$ as can be seen Fig 1 . Thi-Qar governorate is a part of the Mesopotamian plain and a small sector of the southern desert plateau. The Mesopotamian plain can be physio graphically separated into two areas: the active flood plain area on both sides of the Euphrates and the Al-Graf rivers. The abandoned flood plain between the above-mentioned 
rivers the exposed geological formations range in age from Middle Eocene, represented by the Dammam Formation up to lower [9]. Most of the sediments with exposure in the study area are from the sediment of modern rivers, Tigris and Euphrates, Shatt al-Arab, it includes deposits of the bottom of the river, their banks, and sediment of the flood, which is added to the sediment chemical gypsum, carbonates, and fossils, though most of these sediments are sand, silt, and clay origin. [10] This formation extends along the edges of southern and south-western ALHammar marsh and Euphrates River within the slopes of low-lying. It consists of the formation of limestone cretaceous white, especially in the southwest of Al-Nasiriyah city. [11].

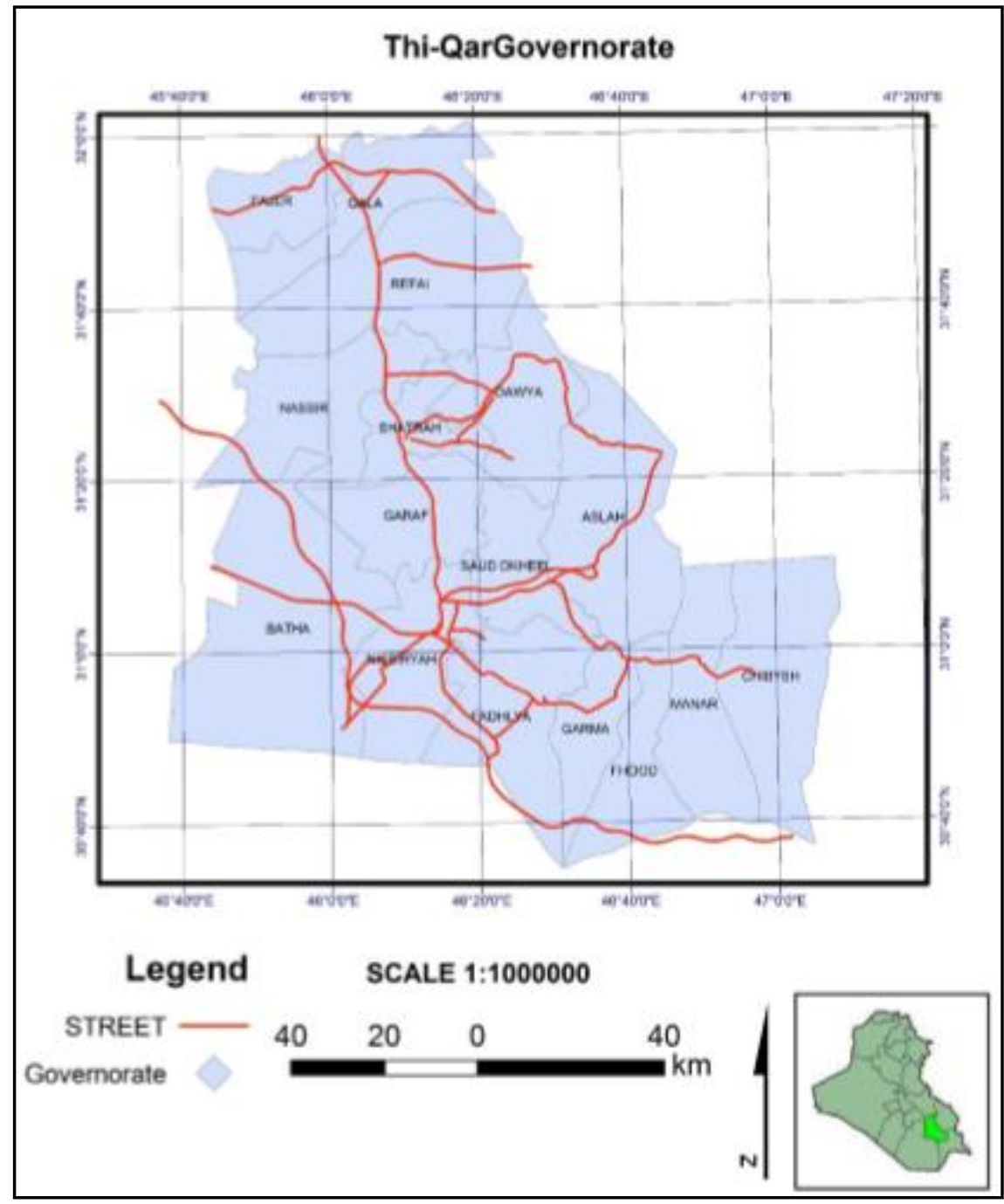

Fig. 1. The study area, source: researcher by Arc-map GIS v.9.3. 


\subsection{Data Collection}

To gridding and interpolation of well log data for building lithological model, the reports of soil investigation were collected from many possible sources (such as AETL, NCCLR, Al-Mawal, Al-Mustanserya University, Basra University, and (some other private sector laboratory). The reports included the results of standard laboratory tests regarding the physical properties such as $\gamma$ dry unit weight, initial void ratio, and grain size analysis of engineering properties of soil such as standard penetration test (S.P.T), unconfined compressive strength (qu), compression index (cc), chemical soil properties such as sulphate ions (\%SO3) and (Water Table Level (W.T.L). The water table level at the time of testing was recorded, and the elevation of the surface at the borehole location was noticed. Some properties were calculated from interpolation between other properties of the study area busied on computerized techniques. The position of each borehole was determined approximately from many methods such as coordinate available in the report itself by GPS instrument which was used much and database map. All data used to build geodatabase in Arc-Map GIS 9.3 as Fig 2. The number of the borehole is (205) because of many constraints in the field they become (76) boreholes as Fig 3.

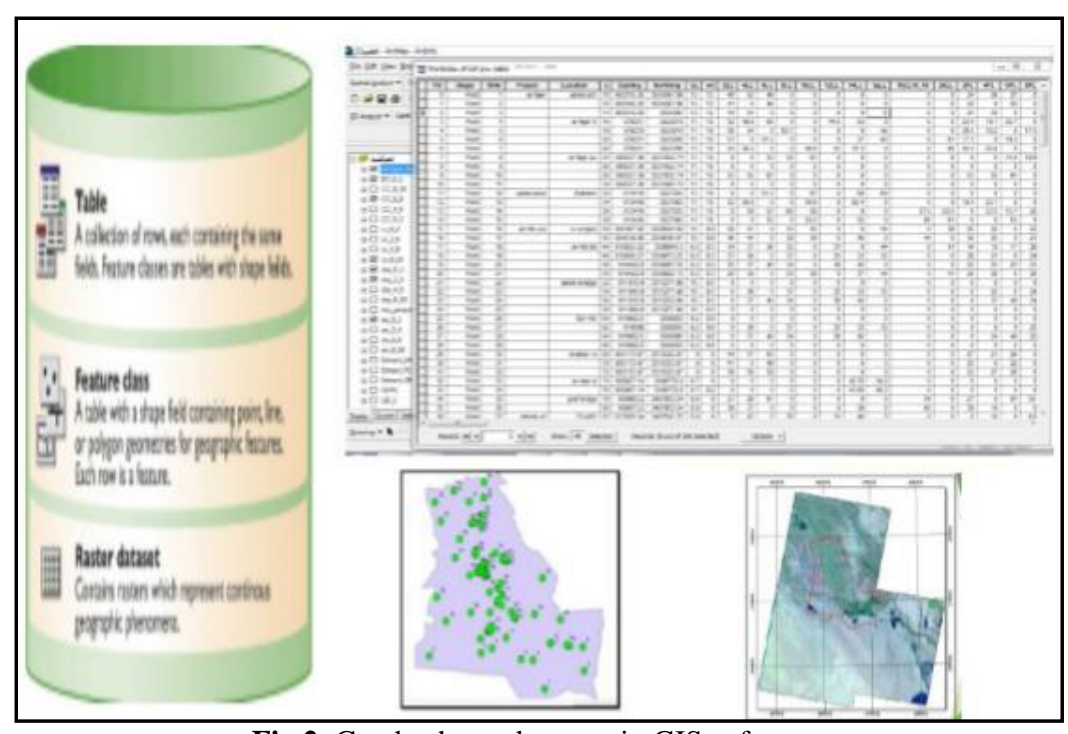

Fig.2. Geodatabase elements in GIS software. 


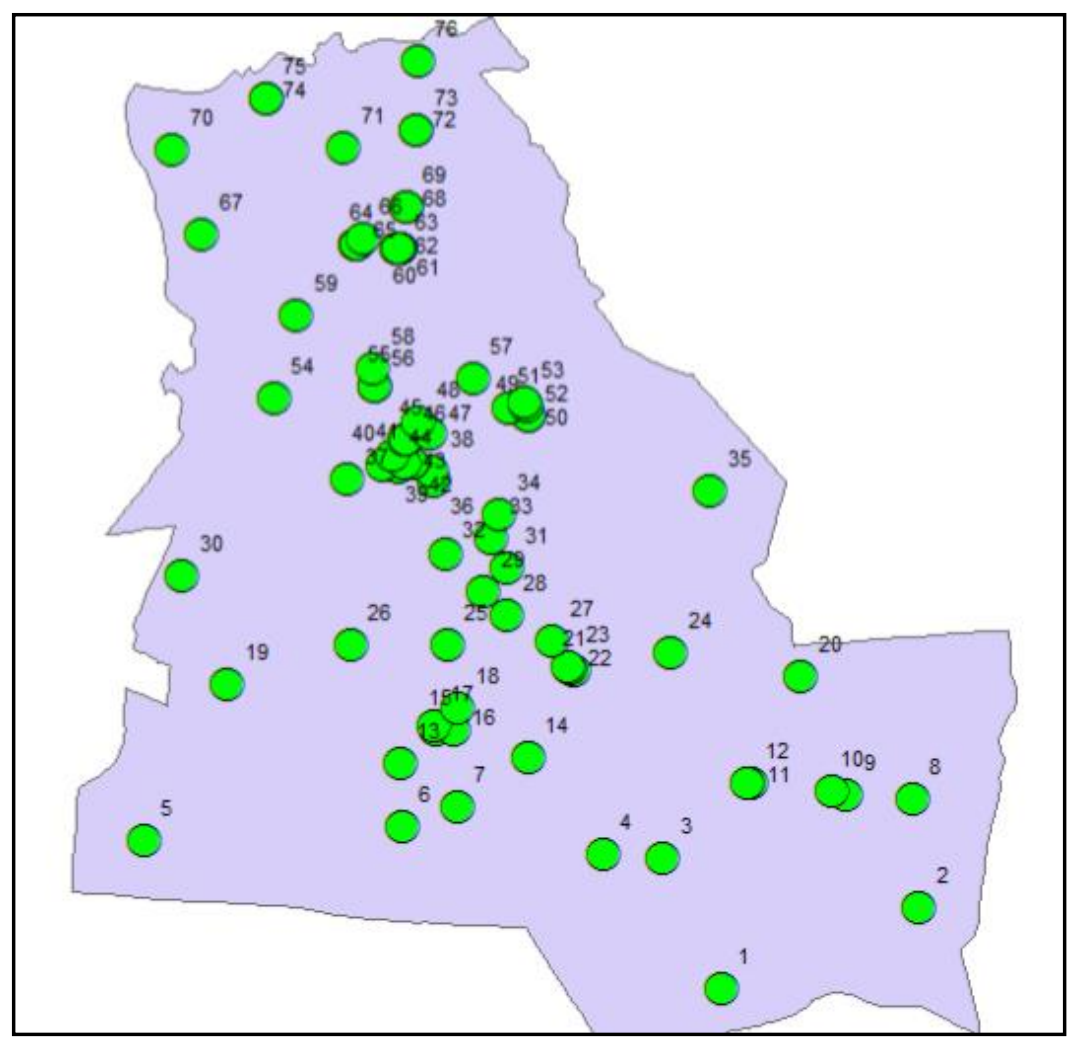

Fig. 3. Distribution of borehole location, Source: researcher by-map GIS v.9.3 depend on laboratory investigate from( AETL, NCCLR, Al-Mawal, Al-Mustanserya University, and Al-Basra University (besides private sector laboratory).

Besides the borehole there was a Topography section as in Fig 4. that represented the elevation between points set by its location as in Fig 5 .

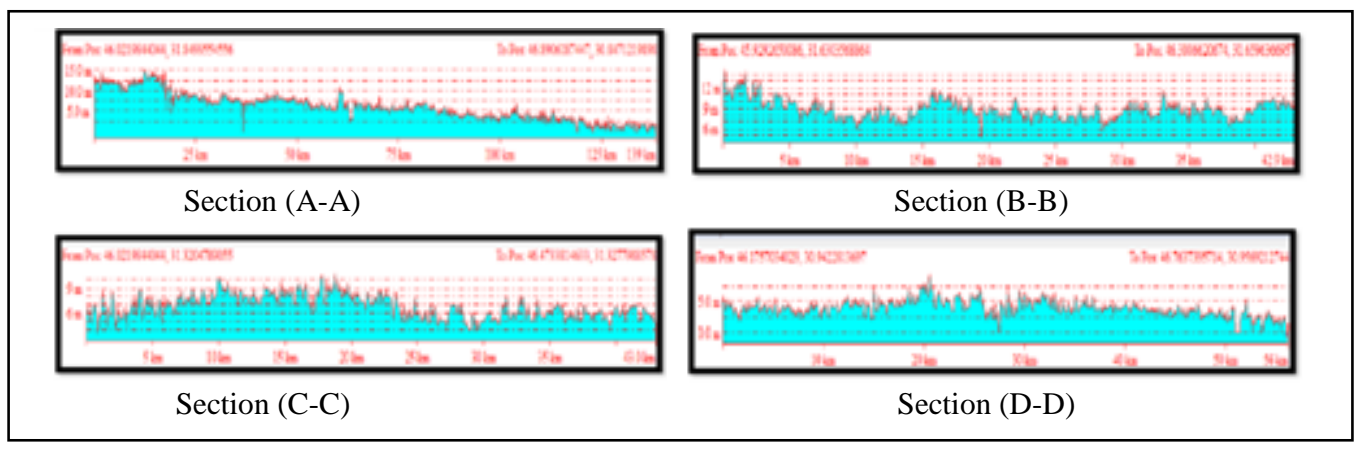

Fig. 4 borehole Sections by the global mapper. 


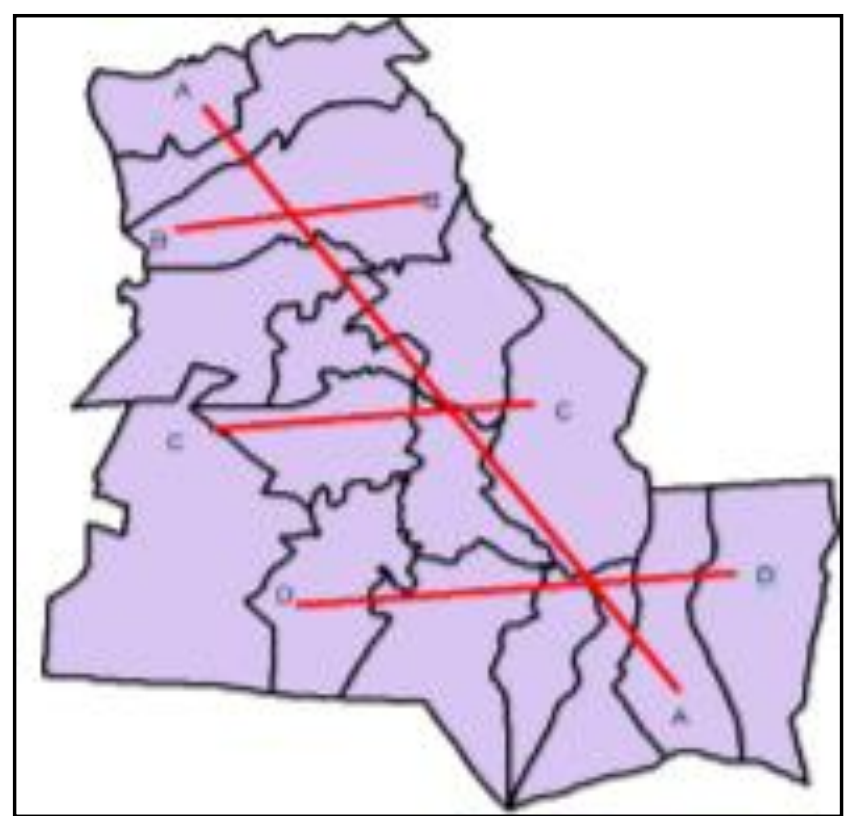

Fig. 5 Topography section, Source: researcher by Arc-map GIS v.9.3.

Wherever spectral reflectance characteristics of features on the earth's surface can be quantified by the proportion of energy reflected by the feature at different wavelengths. So, characteristics of several surfaces can illustrate the spectral which may be of interest in civil engineering [12]. Such as in Fig 6 to classification the surface as a 2D plan.

Rock Works Modelling Techniques by using (Rock Work v.15). The study depends on using well $\log$ data such as Bearing capacity $(\mathrm{t} / \mathrm{m} 2)$ shows in Figure 10, and the techniques of lithological model available in rock works.

This software package is used for this study due to its friendly user interface, capabilities in managing borehole and well log data. The complex geological sitting forms the background of the lithological model that aims to develop a voxel-based 3D model from the available borehole data.

So, in Fig 7 the Longitudinal section between two points (AA) that show in Fig 5 from the study area, same as in Fig 8 shows the Longitudinal section between two points (CC). 


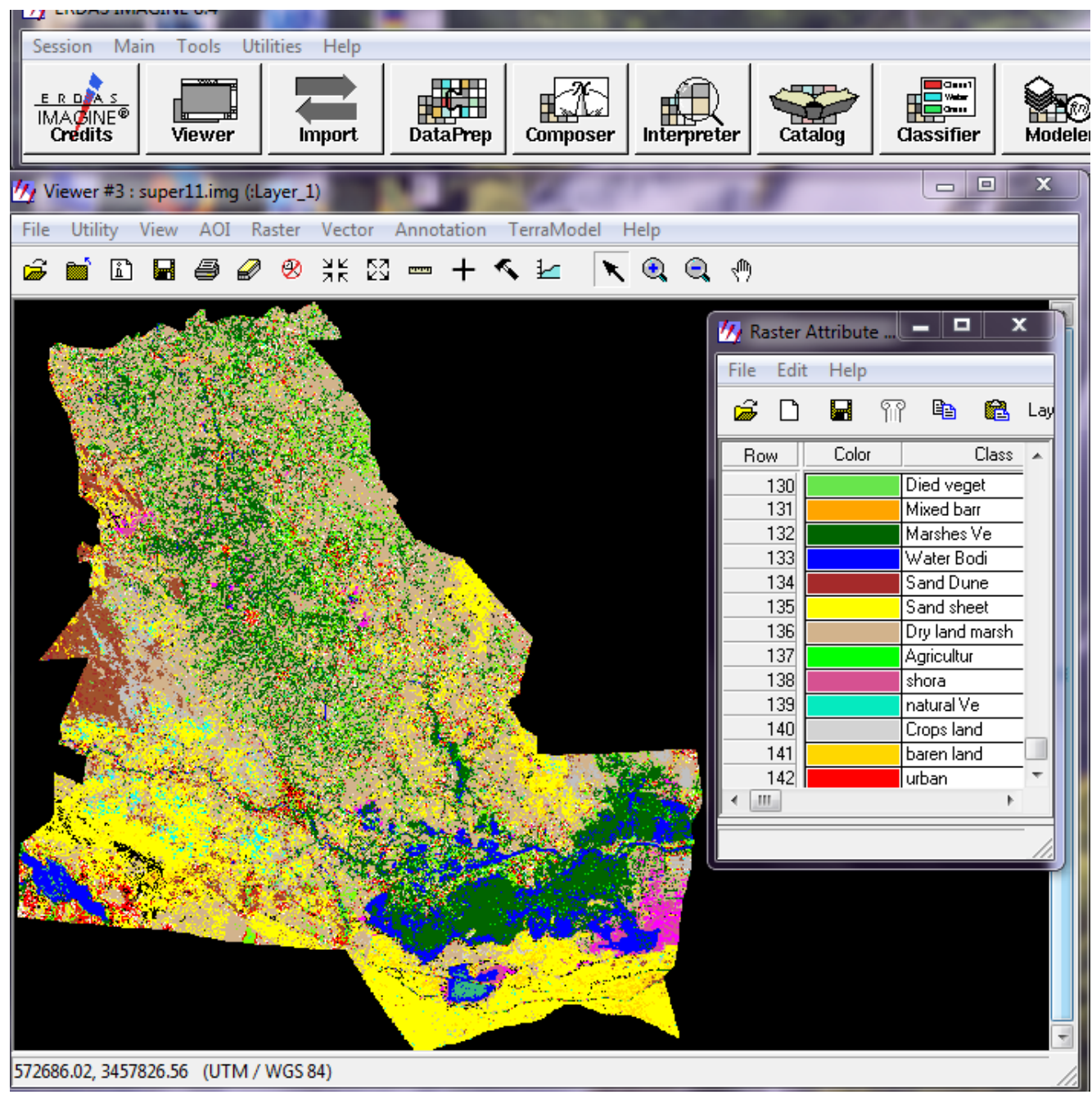

Fig .6. Classification Map of Thi-Qar governate By Erdas 8.4 from Landsat-7 ETM 2011. 


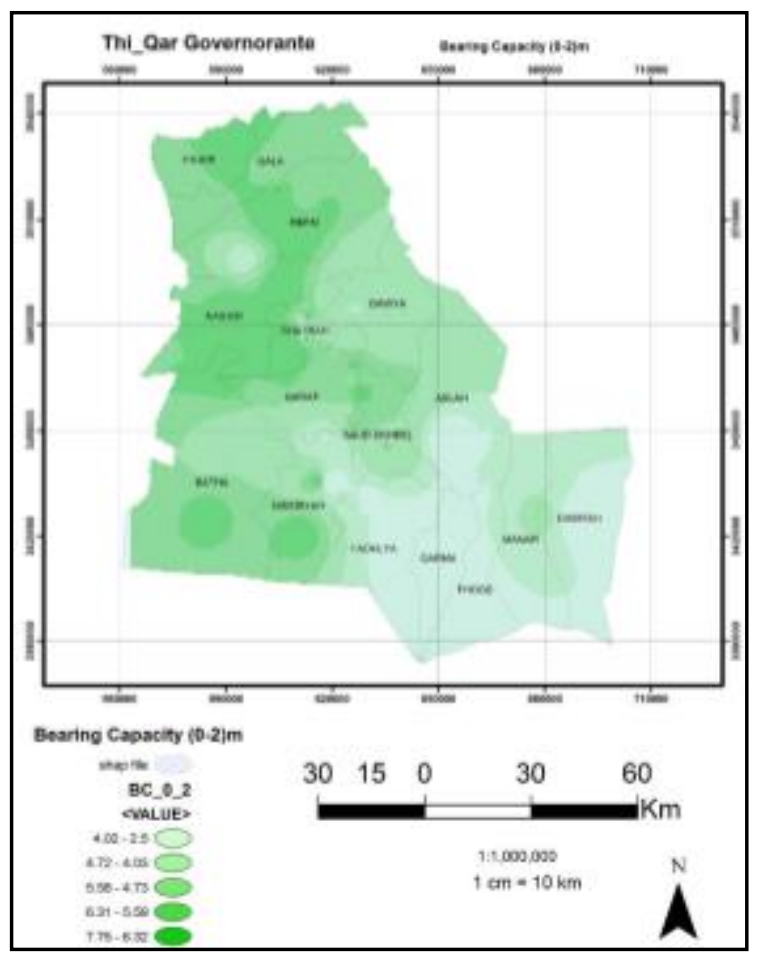

Fig.7. Bearing capacity $\left(\mathrm{t} / \mathrm{m}^{2}\right)$,source: researcher by Arc-map GIS v.9.3.

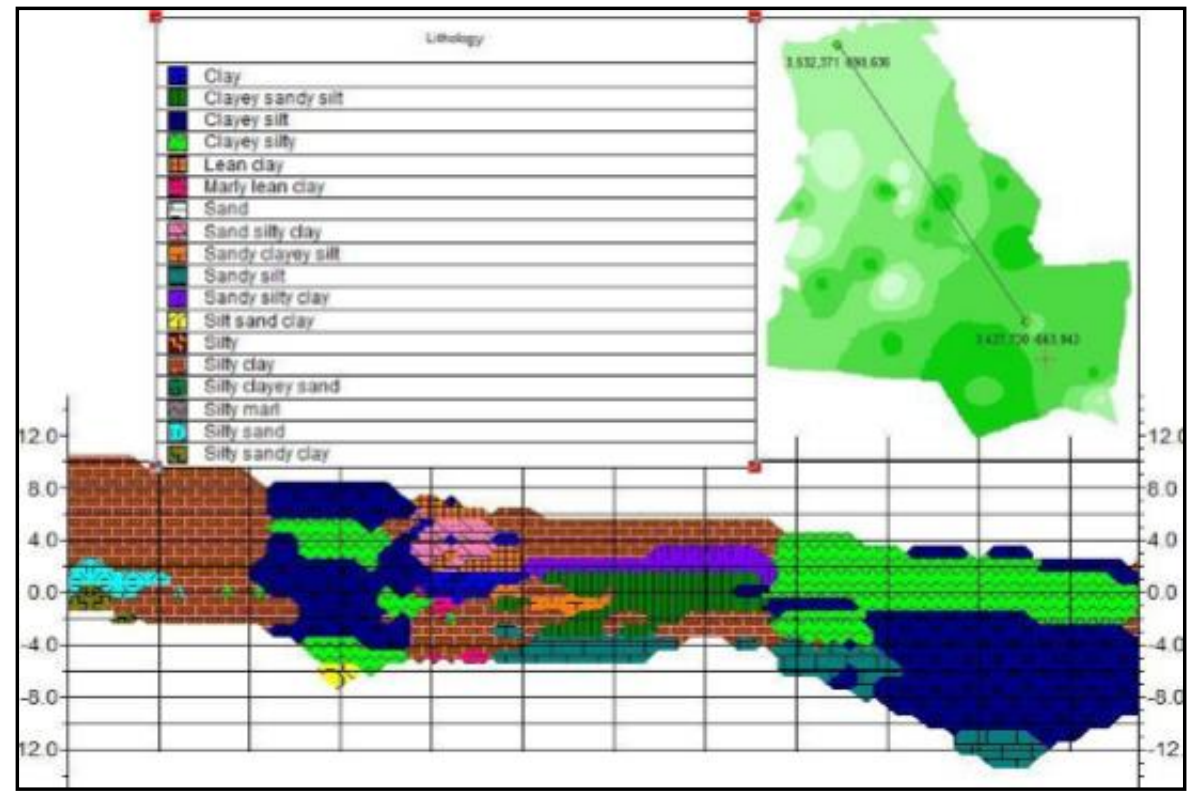

Fig.8. Longitudinal section from Al-Fajer to Al-Chibish distract source: integration between Arc-map GIS v.9.3 and Rockwork v.15 programs. 


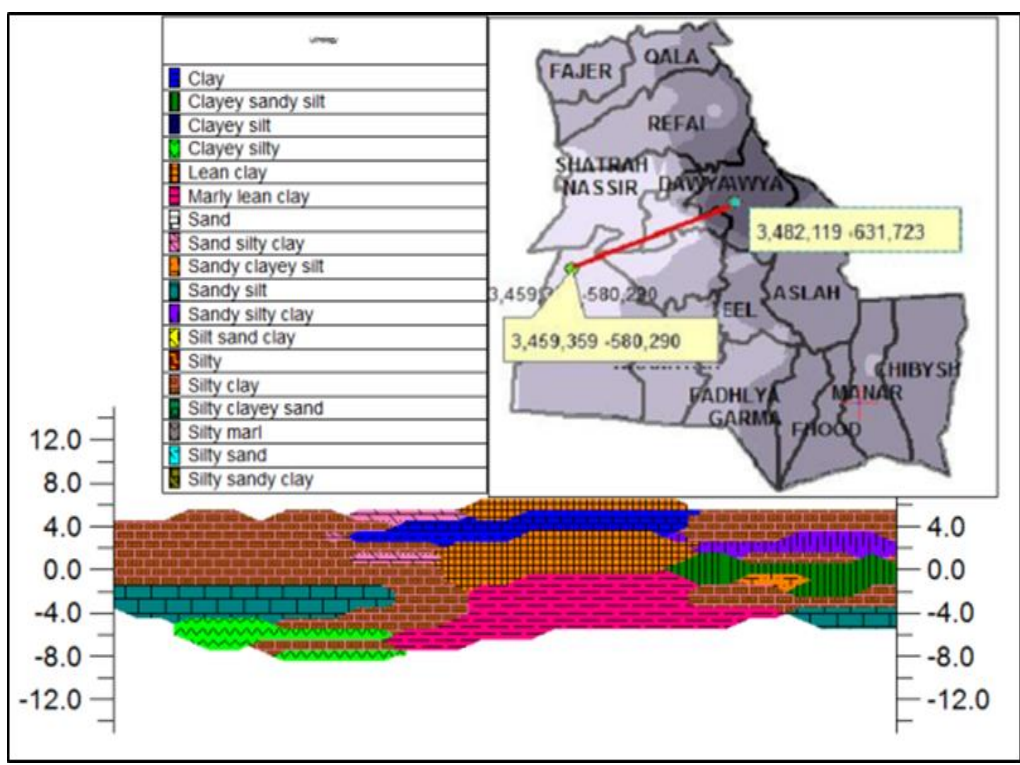

Fig.9. Longitudinal section from Al-Bat-ha to Al-Dawya district, source: integration between Arc-map GIS v.9.3 and Rockwork v.15 programs.

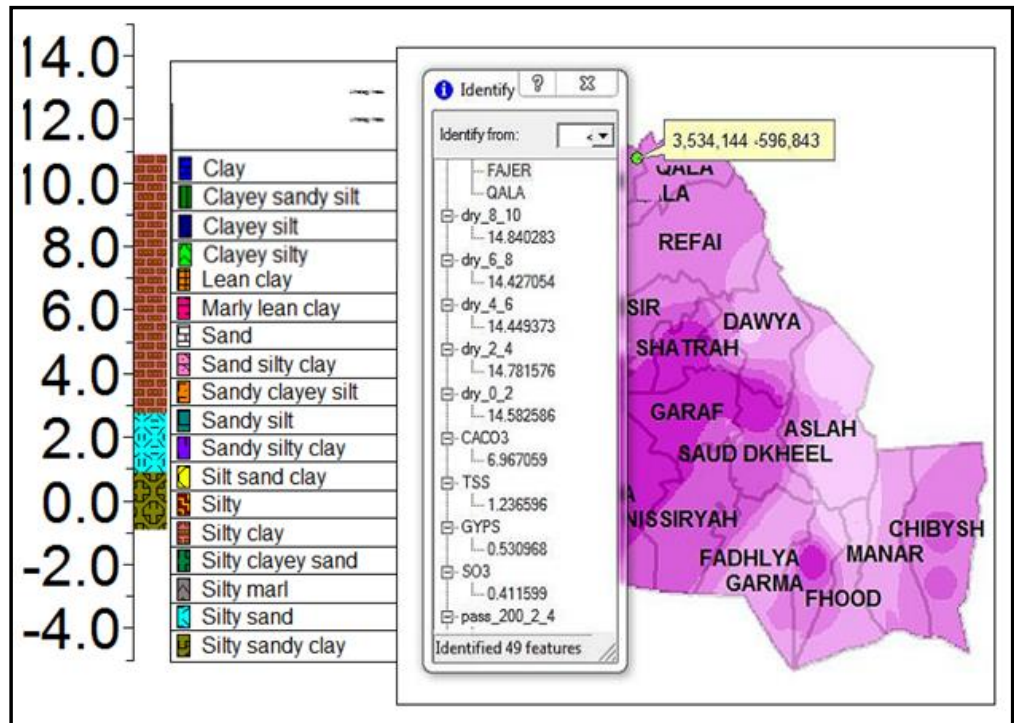

Fig. 10. Borehole (3) section with soil properties, source: integration between Arc-map GIS v.9.3 and Rockwork v.15 programs.

\section{Results and discussions}

By integrating between Arc-map GIS 9.3 and Rockwork 15 and result of all programs the $3 \mathrm{D}$ model product as in Fig. 15. The results show that the difference of ground level from north to south is $10 \mathrm{~m}$, the soil is silty clay with a bearing capacity range (2-7) t/m2. An empirical 
correlation is obtained by relating the overburden pressure with depth this relation has (R2=0.8842) and SPT with depth which has (R2=0.6845).

The results of this research showed that the soil in the study area is clay silt with a small amount of sand in some regions in different depths and the water table is between $(0.1-1.9) \mathrm{m}$ below the natural ground surface (N.G.S). The results also showed that number values $(\mathrm{N})$ of the standard penetration test (SPT) is between (4-63) blows. The moisture content (M.C) is between (16.2\%$32.4 \%$ ) of the sample's weight. Plasticity index (P.I) is (4\%-53\%), Liquid limit (L.L) of soil is between (29\%-63\%), the plastic limit (P.L) is (3\%-43\%) and the evaluation bearing capacity of soil at shallow (0-2) $\mathrm{m}$ between $(2.5-7.75) \mathrm{t} / \mathrm{m} 2$, the soil classified to salty-clay with loos medium-very dense which is a wide range. The results of chemical tests of soil showed that the sulphate contact of soil is between $(0.23-0.71) \%$, total soluble salts (T.S.S.) between (0.02-2.9) $\%$, and gypsum content between $(0.16-0.62)$ percent. The investigation and lab test showed that soil needs engineering treatments before constructing any building on it. Table 1.

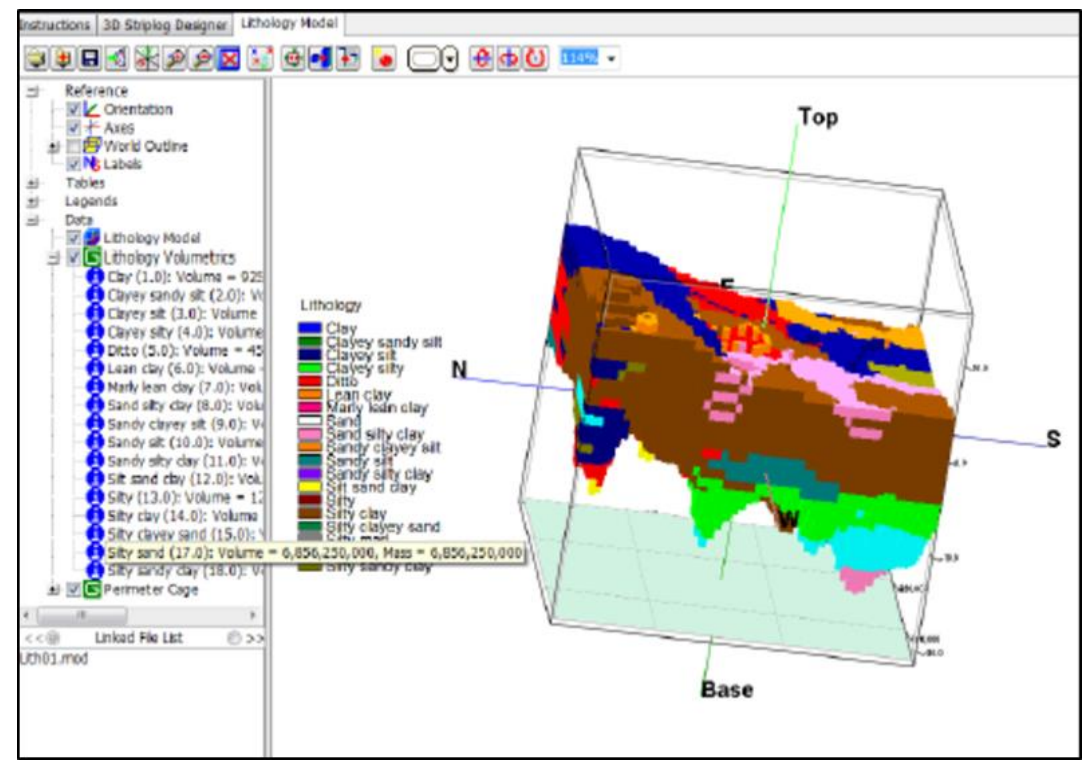

Fig. 11. Lithology model of the study area by Rock work v.15.

Table 1. results of the geotechnical map.

\begin{tabular}{|c|c|c|c|c|c|c|c|c|c|c|c|c|c|}
\hline $\begin{array}{l}\mathrm{D} \\
\mathrm{m}\end{array}$ & $\begin{array}{l}\text { B.C } \\
\text { T/M }{ }^{2}\end{array}$ & LL\% & PI\% & $\begin{array}{l}\text { Dry } \\
\text { Density } \\
\text { KN/M }\end{array}$ & $\begin{array}{l}\text { Specific } \\
\text { Gravity }\end{array}$ & $\begin{array}{l}\text { CU } \\
\text { kap }\end{array}$ & eo & $\mathrm{cc}$ & $\mathrm{cr}$ & $\begin{array}{l}\text { Sieve } \\
\text { Analysis\% } \\
\text { Passing } \\
\text { No. } 200\end{array}$ & Gyp.\% & $\begin{array}{l}\text { TSSP } \\
\text { PM }\end{array}$ & SPT \\
\hline $0-2$ & $\begin{array}{l}5.5- \\
6.5\end{array}$ & 45 & 24 & 15 & 2.68 & 105 & 0.67 & 0.2 & 0.04 & 94 & 0.46 & 2.18 & 5 \\
\hline $2-4$ & $\begin{array}{l}6.5- \\
7.5\end{array}$ & 50 & 27 & 16 & & 123 & 0.64 & 0.21 & 0.04 & 89 & & & 7 \\
\hline $4-6$ & & 52 & 27 & 15 & & 119 & 0.62 & 0.23 & 0.03 & 83 & & & 10 \\
\hline
\end{tabular}

All data collection completed on $1 / 1 / 2014$ and product programs results as a model and geotechnical map as well as Table (1) Fig 12. After that on 27/3/2014 at the location (611603E- 
$3477068 \mathrm{~N}$ ) in the study area laboratory test was taken as a result in Table 2 . Then the researcher compared two cases that give accuracy of geotechnical map was more than $80 \%$.

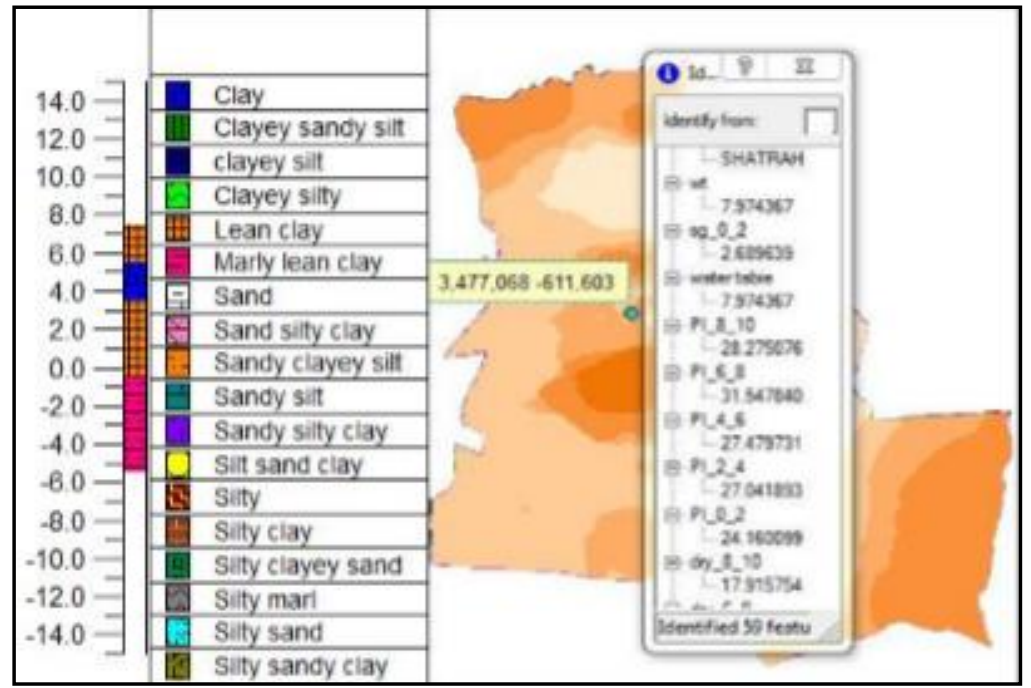

Fig. 12. lithology and soil properties from the soil report, source: integration between Arc-map GIS v.9.3 and Rockwork v.15 programs.

Table 2. results of the soil report.

\begin{tabular}{|c|c|c|c|c|c|c|c|c|c|c|c|c|c|}
\hline $\begin{array}{l}\mathrm{D} \\
\mathrm{m}\end{array}$ & $\begin{array}{l}\text { B.C } \\
\text { T/M }\end{array}$ & LL\% & $\mathrm{PI} \%$ & $\begin{array}{l}\text { Dry } \\
\text { Density } \\
\text { KN/M }\end{array}$ & $\begin{array}{l}\text { Specific } \\
\text { Gravity }\end{array}$ & $\begin{array}{l}\mathrm{CU} \\
\text { kap }\end{array}$ & eo & $\overline{c c}$ & cr & $\begin{array}{l}\text { Sieve } \\
\text { Analysis\% } \\
\text { Passing } \\
\text { No.200 }\end{array}$ & Gyp.\% & $\begin{array}{l}\text { TSSP } \\
\text { PM }\end{array}$ & $\overline{\text { SPT }}$ \\
\hline $0-2$ & $\begin{array}{l}5.5- \\
6.5\end{array}$ & 47 & 32 & 15 & 2.7 & 61 & 0.58 & 0.21 & 0.03 & 96 & 2.75 & 8.1 & \\
\hline $2-4$ & $\begin{array}{l}7.5- \\
8.0\end{array}$ & 50 & 32 & 15 & & 195 & 0.69 & 0.2 & 0.03 & 91 & & & 11 \\
\hline 4-6 & $\begin{array}{l}8.0- \\
9.0\end{array}$ & 52 & 20 & 15 & & 158 & 0.68 & 0.22 & 0.03 & 83 & & & 12 \\
\hline
\end{tabular}

\section{Conclusions}

A laboratory test and geotechnical model from programs were carried out to characterize and discuss the various formations constituting the soil of Thi-Qar governorate province. Accordingly, the following conclusions are obtained:

1. Al-Nasiriya soil stratification is erratic and, depositions conditions.

2. Due to the integration between Rock Works \& Arc-Map GIS to produce 3D visual digital geotechnical maps to the study area, which employed the geotechnical techniques are representative many characteristics such as easy used, saved time, and cost, as well as represented ground in the 3D geotechnical model in real vision a simple manner. 
3. The geotechnical model lithology gives an accuracy of more than $80 \%$. That depending on the distance between boreholes, and their number, as well as distribution in the study area.

4. The thematic map of supervised classification (12classes used) gives a good representation of some classes and merges the others

\section{References}

[1] Stalin, V. K., and Muttharam, M.Geotechnical Characterisation and Geoenvironmental Engineering: IGC 2016. Springer; 2018.p.37.0

[2] Wood, D. M., (2003). Geotechnical modelling (Vol. 1).CRC press, pp: 311-318.

[3] Mohammed, I. H., Accuracy Assessment of 2D and 3D Geometric Correction Models for Different Topographic Regions in Iraq .M.Sc. Thesis, Baghdad, Iraq: University of Technology,2011.

[4] Strom, Steven R. Charting a course toward global navigation. The Aerospace Corporation: Crosslink 2002.

[5] Ethaib, Saleem. Solid waste situation in Thi-Qar governorate. In IOP Conference Series: Materials Science and Engineering, IOP Publishing, 2019; 584(1): p. 012023.

[6] Al-Baghdadi, N. H. Geotechnical mapping of An-Najaf City, Iraq. J. University of Babylon, 2016; 24(4):pp. 962-22.

[7] Al-Taie, A. J. (2015). Profiles and geotechnical properties for some Basra soils. Al-Khwarizmi Engineering Journal, 11(2), 74-85.

[8] Ayman A. Ahmed. Using lithological modelling techniques for aquifer characterization and groundwater flow modelling of the Sohag area, Egypt,Faculty of Science, Sohag University, Geology Department, 2009.

[9] Jassim, Saad Z., Jeremy C. Goff. Geology of Iraq. London: DOLIN, sro, distributed by Geological Society of London, 2006. p.341.

[10] Albadran., B.N.,Sedimentology and mineralogy of the Al-Hammar Marsh /Southern Iraq, Marsh Bulletion, 2006. p.33.

[11] Jassim, S. Z., Karim. S. A., Basi. M., Al-Mubarak. M. A. and Munir. J. Final Report on the Regional Geological Survey of Iraq. VOL. 3 Stratigraphy. Manuscript report. Geological Survey of Iraq.1984.

[12] Behdinian, B. Generating Orthoimage from IKONOS Data, Asian Conference on Remote Sensing (ACRS), Taiwan. 2002. 